\title{
Hymenopteran Parasitoids Diversity Associated with Organic and Coventional Agroecosystems in West Sumatera, Indonesia
}

\author{
Yaherwandi $^{\#}$ and Hidrayani ${ }^{*}$ \\ \# Plant Pest and Diseases Department, Agriculture Faculty Andalas University, Padang, 25163, Indonesia \\ E-mail: yaherwandi@faperta.unand.ac.id
}

\begin{abstract}
The use of pesticides in agricultural ecosystems does not only cause environmental pollution, but also impovert diversity of natural enemies such as parasitoids and predators as well as causes the emergence of pests resistance to pesticides. The study was focused to identify and compare the abundance, diversity and evenness of Hymenopteran parasitoid species in organic and conventional agroecosystems. This research was conducted in several organic and conventional vegetable agroecosystems in West Sumatera. The tools used for the collection of insects were farmcop, sweep net and yellow pan traps. A total of 717 individuals of Hymenopteran parasitoids belonging to 21 families and 131 species were recorded during the study. A total of 533 individuals collected in organic agroecosystem consisted of 20 families and 85 species of Hymenopteran parasitoids, whereas in conventional agroecosystems there were 184 individuals collected cosisted of 13 families and 46 species of Hymenopteran parasitoids. This study also demonstrated a strong relationship between crops and Hymenopteran parasitoid composition. Species diversity and evenness of Hymenopteran parasitoids were higher in organic than in conventional agroecosystems.
\end{abstract}

Keywords - Hymenopteran, parasitoid, organic agroecosystem, diversity

\section{INTRODUCTION}

West Sumatera is one of the potential provinces for vegetables in Indonesia. The farmers usually grow vegetables such as broccoli, cabbage, cauliflower, cabbage and caysin. In 1991, the harvested area of vegetatables were 957 ha with production 30.816 tons / ha. In 2002, the harvested area increased to 1,009 ha with production 64.760 tons/ha (Dinas Pertanian Tanaman Pangan dan Perkebunan Provinsi Sumatera Barat, 2002). In 2005 and 2006, the production decreased 25.93 tons/ha and 21.35 tons/ha respectively [7]

One of constraints faced by cabbage farmers is plant pests and diseases attack. The main pests often cause loss are Plutella xylostella Linn (Lepidoptera: Noctuidae), Crocidolomia pavonana Fab (Lepidoptera: Pyrallidae), Liriomyza huidobrensis Blanchard (Diptera: Agromycidae), Spodoptera litura Linn (Lepidoptera: Noctuidae), and Agrotis epsilon (Lepidoptera: Noctuidae). These pests could cause yield loss up to $100 \%$, if they are not controlled [18].

Until now the farmers still use synthetic pesticides to control pests and diseases in vegetables. The use of synthetic pesticides could cause negative effects such as pest resistance to insecticides, secondary pests outbreak, decreased natural enemies biodiversity, environmental pollution and harm to farmers and consumers [14].
For these reasons, alternative controls are neede to reduce reliance on synthetic pesticides which does not cause side effects on the environment. Organic farming is one of practices that implements integrated pest management (IPM), which environmentally friendly. Today, organic farming is being developed for the management of plant pests and diseases in Indonesia, including in West Sumatra.

Organic farming is a cultivation technique that relies on natural ingredients without the use of synthetic chemicals [3]. Organic farming is one of the habitat management techniques that can increase the population and diversity of natural enemies, so as to suppress pest populations.

Organic farming can conserve natural enemies because there are wild flowering plants in the surrounding. Wild flowering plants are additional food sources for natural enemies adults such as pollen and nectar. In addition, wild flowering plants can also serve as migration corridors between habitats for natural enemies [21]. Reference [10] indicated that diversity of natural enemies community, including Hymenopteran parasitoids was higher in organic agroecosystem than in conventional one. Similar study was reported by [1] that the community of Hymenopteran parasitoids was higher in organic vegetables than in conventional one.

To support development of organic agroecosystem in West Sumatera accurate information about the diversity and bioecology of Hymenopteran parasitoids is needed. To 
determine the presence and diversity of the parasitoids a study on Hymenopteran parasitoids diversity associated with organic and conventional agroecosystem was conducted in West Sumatera". The objectives of study were to collect, identify and compare the abundance, species diversity and evenness of Hymenopteran parasitoids in organic and conventional agroecosystems.

\section{MATERIALS AND METHODS}

The research was conducted in organic and conventional vegetables crops in aie Angek village, District of Tanah Datar. Identification of Hymenopteran parasitoids was conducted at the Laboratory of Insect bioecology, Department of Plant Pests and Diseases Faculty of Agriculture, Andalas University. The experiment was conducted from April 2008 to March 2009.

Sample plots were taken systematically on a diagonal line of organic and conventional fields. On the diagonal line in each of organic and conventional vegetable agroecosystems, 5 sample plots were defined with an area of $1 \mathrm{~m}^{2}$ each.

Insects samples at each sample plot were collected using farmcorp, sweep net and yellow pan traps. Farmcorp was used for sucking insects on the plant leaf and stem of vegetable crops. Sweep net was used for collecting insects on vegetable crops. Sweep net was used by swinging the net to the left and right 10 times. Yellow pan trap was mounted in the middle of the vegetable crops and it should not obstruct the vision of insects. Insects attracted to yellow color will come to the yellow pan traps. Yellow pan traps were filled with soapy water to kill insects. Each of yellow pan trap was installed in sample plot for 24 hours.

Identification of Hymenoptera parasitoids was done in Laboratory of insects bioecology, plant Pest and Diseases Department, Faculty of Agriculture Andalas University. Insects collected from the fields were separated based on the order. Order of Hymenopteran parasitoids were identified to family and morphospecies level (coded only). Identification of Hymenoptera parasitoids to family level was done using reference books of [9], [15] and the standard collection of Hymenopteran parasitoids in laboratory of insects bioecology, Plant Pest and Diseases Department, Faculty of Agriculture Andalas University.

Diversity of Hymenopteran parasitoids were analyzed using the Shannon -wienner and Simpson's evenness index [13], [19] and [11]. Primer version 5 for Window was used to calculate the Shannon-Wienner and Simpson's diversity index.

\section{RESULTS AND DISCUSSION}

\section{A. Community of Hymenopteran parasitoids}

A total of 717 individuals of Hymenopteran parasitoids were collected consisting of 21 families and 131 species and in this study. In organic agroecosystems 533 individuals were collected consisting of 20 families and 85 species, whereas in conventional one 184 individuals were collected, consisting of 13 families and 46 species (Table 1). These results indicated that abundance, number of species and families of Hymenopteran parasitoids in organic agroecosystems were higher than conventional one. Reference [4] reported that abundance of beneficial arthropods was higher in organic than conventional agroecosistems in south-central Ontario, Canada.

In this study, Ichneumonids were more dominant than other families. In organic agroecosystems there were 200 individuals of Ichneumonids consisting of 25 species, whereas in conventional one there were 43 individuals consisting of 12 species. Ichneumonid was one of the largest families in order of Hymenoptera. This family has more or less 60,000 species throughout the world and a common insect groups in terestorial habitat [5]. It is concluded that the Ichneumonidae was a dominant family of Hymenopteran parasitoids in organic vegetable crops in Aia Angek.

In organic vegetable agroecosystems there were 78 individuals of Braconidae family belonging to 15 species, whereas in the conventional it was found 81 individuals consisting of 9 species. The second largest group of parasitoids found in this study was the family of Braconidae. The same results was also found by [2] and [16] that the family of Ichneumonidae and Braconidae were two families of Hymenoptera having the highest abundance and species richness in vegetable crops and other teresterial habitats.

TABEL I

COMMUNITY OF HYMENOPTERA PARASITOID IN ORGANIC AND CONVENTIONAL AGROECOSYSTEM

\begin{tabular}{|c|c|c|c|c|}
\hline \multirow{2}{*}{ Famili } & \multicolumn{2}{|c|}{ Conventional } & \multicolumn{2}{|c|}{ Organic } \\
\hline & $\begin{array}{c}\text { Num. of } \\
\text { Individuals }\end{array}$ & $\begin{array}{l}\text { Num. of } \\
\text { Species }\end{array}$ & $\begin{array}{c}\text { Num. of } \\
\text { Individuals }\end{array}$ & $\begin{array}{l}\text { Num. of } \\
\text { Species }\end{array}$ \\
\hline Betylidae & 1 & 1 & 1 & 1 \\
\hline Braconidae & 81 & 9 & 78 & 15 \\
\hline Calcididae & 0 & 0 & 2 & 2 \\
\hline Ceraphronidae & 0 & 0 & 2 & 1 \\
\hline Crabronidae & 3 & 2 & 8 & 2 \\
\hline Diapriidae & 8 & 3 & 14 & 2 \\
\hline Eucoliidae & 1 & 1 & 2 & 1 \\
\hline Eulophidae & 0 & 0 & 15 & 2 \\
\hline Evaniidae & 0 & 0 & 1 & 1 \\
\hline Halictidae & 3 & 2 & 2 & 1 \\
\hline Ichneumonidae & 43 & 12 & 200 & 25 \\
\hline Megaspilidae & 0 & 0 & 2 & 2 \\
\hline Mutilidae & 8 & 3 & 43 & 9 \\
\hline Nyssonidae & 9 & 4 & 65 & 9 \\
\hline Pteromalidae & 0 & 0 & 1 & 1 \\
\hline Scelionidae & 22 & 5 & 63 & 6 \\
\hline Sclerogibbidae & 1 & 1 & 9 & 1 \\
\hline Stenotridae & 0 & 0 & 1 & 1 \\
\hline Tetracampidae & 1 & 1 & 0 & 0 \\
\hline Tiphiidae & 0 & 0 & 1 & 1 \\
\hline Vespidae & 3 & 2 & 23 & 2 \\
\hline Total & 184 & 46 & 533 & 85 \\
\hline
\end{tabular}




\section{B. Community of Hymenoptera parasitoids in vegetable crops}

In organic vegetable crops Hymenoptera parasitoids were collected on Broccoli, Cabbage and Lettuce, whereas in conventional one it was only done on cabbage. In study sites, conventional agroecosystems only one species of crop was planted (monoculture). In Broccoli 104 individuals were collected belonging to 17 families and 43 species. In cabbage 288 individuals were collected, and 17 families and 67 species. In lettuce 51 individuals were collected, 10 families and 26 species. In cabbage crops (conventional vegetable) 184 individuals of Hymenopteran were collected consisting of 46 species and 13 families (Table 2).

In table 2 it appeared that the community structure of Hymenoptera parasitoids on cabbages was more complex than in other crops. In all three types of plants grown in organic and conventional farming it was seen that the family Ichneumonidae, Braconidae and Scelionidae were the dominant family. This suggests that the species of Ichneumonidae, Braconidae and Scelionidae are the most widely associated with vegetable crops.

TABEL II

COMMUNity OF HyMENOPTERA PARASITOID ON ORGANIC AND Conventional Vegetable Agroecosystems

\begin{tabular}{|l|c|c|c|c|c|c|c|c|}
\hline \multirow{4}{*}{ Family } & Conventional & \multicolumn{6}{c|}{ Organic } \\
\cline { 2 - 11 } & \multicolumn{2}{|c|}{ Cabbage } & \multicolumn{2}{|c|}{ Broccoli } & \multicolumn{2}{c|}{ Cabbage } & \multicolumn{2}{c|}{ Lettuce } \\
\cline { 2 - 10 } & $\begin{array}{c}\text { Num. } \\
\text { of } \\
\text { indiv }\end{array}$ & $\begin{array}{c}\text { Num. } \\
\text { of } \\
\text { Sp }\end{array}$ & $\begin{array}{c}\text { Num } \\
\text {.of } \\
\text { indiv }\end{array}$ & $\begin{array}{c}\text { Num } \\
\text {.of } \\
\text { Sp }\end{array}$ & $\begin{array}{c}\text { Num. } \\
\text { of } \\
\text { indiv }\end{array}$ & $\begin{array}{c}\text { Num } \\
\text { of } \\
\text { Sp }\end{array}$ & $\begin{array}{c}\text { Num. } \\
\text { Of } \\
\text { indiv }\end{array}$ & $\begin{array}{c}\text { Num. } \\
\text { of } \\
\text { Sp }\end{array}$ \\
\hline Betylidae & 1 & 1 & 0 & 0 & 1 & 1 & 0 & 0 \\
\hline Braconidae & 81 & 9 & 31 & 11 & 39 & 11 & 8 & 2 \\
\hline Ceraphronidae & 0 & 0 & 1 & 1 & 1 & 1 & 0 & 0 \\
\hline Chalcididae & 0 & 0 & 2 & 1 & 0 & 0 & 0 & 0 \\
\hline Crabronidae & 3 & 2 & 3 & 1 & 4 & 2 & 1 & 1 \\
\hline Diapridae & 8 & 3 & 5 & 2 & 8 & 2 & 1 & 1 \\
\hline Eucolidae & 1 & 1 & 1 & 1 & 1 & 1 & 0 & 0 \\
\hline Eulophidae & 0 & 0 & 3 & 1 & 11 & 1 & 1 & 1 \\
\hline Evaniidae & 0 & 0 & 1 & 1 & 0 & 0 & 0 & 0 \\
\hline Halictidae & 3 & 2 & 1 & 1 & 1 & 1 & 0 & 0 \\
\hline Ichneumonldae & 43 & 12 & 71 & 20 & 116 & 22 & 13 & 8 \\
\hline Megaspilidae & 0 & 0 & 1 & 1 & 1 & 1 & 0 & 0 \\
\hline Mutilidae & 8 & 3 & 15 & 8 & 21 & 6 & 7 & 4 \\
\hline Nyssonidae & 9 & 4 & 27 & 6 & 30 & 8 & 8 & 3 \\
\hline Pteromalidae & 0 & 0 & 0 & 0 & 1 & 1 & 0 & 0 \\
\hline Scelionidae & 22 & 5 & 14 & 2 & 41 & 5 & 8 & 4 \\
\hline Sclerogibbidae & 1 & 1 & 4 & 1 & 2 & 1 & 3 & 1 \\
\hline Stenotridae & 0 & 0 & 1 & 1 & 0 & 0 & 0 & 0 \\
\hline Tetracampidae & 1 & 1 & 0 & 0 & 0 & 0 & 0 & 0 \\
\hline Tiphiidae & 0 & 0 & 0 & 0 & 1 & 1 & 0 & 0 \\
\hline Vespidae & 3 & 2 & 13 & 2 & 9 & 2 & 1 & 1 \\
\hline Total & 184 & 46 & 104 & 43 & 288 & 67 & 51 & 26 \\
\hline
\end{tabular}

\section{Diversity of Hymenoptera parasitoids}

Index of richness, evenness, and diversity of Hymenopteran parasitoid species in organic agroecosystems were $83,0.86$ and 3,79 respectively, whereas in conventional one there were $46,0.71$ and 2,72. Index of richness, evenness and diversity of Hymenoptera parasitoid species in organic agroecosystems were higher than conventional ones (Table 3).

TABEL 3.

INDEX OF RICHNESS, EVENNESS, AND DIVERSITY OF HYMENOPTERA PARASITOID SPECIES IN ORGANIC AND CONVENTIONAL AGROECOSYSTEMS

\begin{tabular}{|l|c|c|}
\hline \multicolumn{1}{|c|}{ Index } & $\begin{array}{c}\text { Conventional } \\
\text { Agroecosystems }\end{array}$ & $\begin{array}{c}\text { Organic } \\
\text { Agroecosystems }\end{array}$ \\
\hline Species richness & 46.00 & 83,00 \\
Species evenness & 0,71 & 0,86 \\
Species diversity & 2,72 & 3,79 \\
\hline
\end{tabular}

Table 3 showed that the species diversity of Hymenopteran parasitoids in organic agroecosystems were higher than conventional one. This results was similar to the finding of [10] and [1] who reported species richness and diversity of Hymenopteran parasitoids were higher in organic agroecosystems than conventional one. This was assumed to be due to number of individuals and species of Hymenoptera parasitoids were higher in organic agroecosystems than conventional one (Table 1). In addition to organic agroecosytem were polyculture systems and also many wild flowering plants. The presence of wild flowering plants in organic agroecosystem can provide additional food and shelter to adult of parasitoid and increase the diversity of Hymenopteran parasitoids. Reference [20] reported that wild flowering plants there are on the edge of the main crops can conserve and enhance the species richness of natural enemies.

Evenness index ranges from zero to one, if the index is close to zero, the distribution of insects in an ecosystem is uneven, but if the value of the equity approach it was more equitable distribution of insects [8]. In general, the cultivation of organic agroecosystems were conducted polyculture system by planting various types of plants. Polyculture farming system can increase the diversity of insect community [17]. Reference [12] reported ecosystem with abundant natural resources have a higher diversity of organisms than ecosystems with limited natural resources. In contrast, the conventional agroecosystems (monoculture) consist of one species of plant and the use of synthetic chemical pesticides does not only kill pests, but also kills natural enemies.

\section{CONCLUSIONS}

Species diversity and community structure of Hymenopteran parasitoids were more complex in organic than conventional agroecosystems. The dominant Hymenopteran parasitoids in organic and conventional Agroecosystems were Ichneumonids, Braconids and Scelionids. 


\section{ACKNOWLEDGMENT}

We would like to thank the Director of Directorate General of Higher Education who had funded the research and all who contributed to this research.

\section{REFERENCES}

[1] Agus, YH. Keanekaragaman Collembola, Semut, dan Laba-laba Permukaan Tanah Pada Empat Tipe Penggunaan Lahan [Disertasi] Sekolah Pascasarjana IPB. Bogor. 127 hal. 2007.

[2] Atmowidi, T. Keanekaragaman Morfospesies Hymenoptera Parasitoid dan Senyawa Antiherbivora di Taman Nasional Gunung Halimun Jawa Barat. [Tesis] PPs IPB. Bogor. 1999.

[3] Badan Penelitian dan Pengembangan Pertanian. Prospek Pertanian Organik di Indonesia. Info Aktual, berita Litbang Pertanian. 2005.

[4] Celine, B., Pamela A. M. and Alain, B. Arthropod Diversity as Affected by Agricultural Management (Organic and Conventional Farming), Plant Species, and Landscape Context. Ecoscience 16(4):492-501. 2009.

[5] Department Of Entomology, Hymenoptera. London: International Institute of Entomology. 1992.

[6] Dinas Pertanian Tanaman Pangan dan Perkebunan Provinsi Sumatera Barat. Laporan Tahunan Tanaman Pangan BPTPP Sumatera Barat. 2002

[7] Dinas Perlindungan Tanaman Pangan dan Hortikultura Sumatera Barat. Laporan Tahunan Balai Perlindungan Tanaman Pangan dan Hortikultura Sumatera Barat. 2007.

[8] Elkie, P.C, Rempel RS, karr A.P. Patch Analyst User's Manual: A toll For cuantifiying Landscape Structure. Ontario: Queen's Printer For Ontario. 1999.

[9] Goulet H, Huber 1T. Hymenoptera of The World: And Identiftcation Guide To Families. Ottawa: Agriculture Canada Publication. 1993
[10] Hole, D.G, et. al. Organic Forming Benefit Biodifersity, Biological Conservation. 122: 113-130. 2005

[11] Krebs, C. Ecological Metodology. Second Edition. New York: An Imprint of Addition Wesley Longman,Inc. 1999.

[12] Lawton. J.H. Plant Architecture and The Diversity of Phytophagus Insect. Annu. Rev. Entomol. 28:23-29. 1998.

[13] Maguran, A.E. Ecological Diversity and Measurement. London: Chapman \& Hall. 1988

[14] Marlinda, R. Monitoring Aplikasi Pestisida dan Agens Hayati Serta Analisis Usaha Taninya Pada Tanaman Kubis Bunga. Skripsi Sarjana Pertanian Universitas Andalas. Padang. 37 hal. 2002.

[15] Noyes, J.S. The Diversity Of Hymenoptera In Tropics With Special Reference To Parasitica In Sulawesi. Ecological Entomology 14: 197-207. 1989.

[16] Novita, R. Keanekaragaman Hymenoptera parasitoid pada pertanaman sayuran di Alahan Panjang, Kabupaten Solok Sumatera Barat. [Skripsi] Faperta Unand. Padang. 2007.

[17] Risc, S. J, Andow D and Altieri A. Agroecosystem Diversity And Pest Control: Data, Tentative Conclusions, And New Research Directions. Environ Entomoll2: 625-629. 1983.

[18] Rukmana, R. Budidaya Kubis dan Brokoli. Penerbit Kanisius. Yogyakarta. 61 hal. 1994.

[19] Spellberg, I.F. Monitoring Ecological Change. Meulboume: Cambridge University Press. 1991.

[20] Van Emden, H.F. Plant Dversity and Natural Enemy Efficiency In Agroecosystem. Di dalam: Mackkauer M, Ehler LE, Roland J, editor. Critical Issues in Biological Control. Great Britain: Atheneum Press. Hal 63-80. 1991.

[21] Yaherwandi. Keanekaragaman Hymenoptera Parasitoid Pada Beberapa Tipe lanskap Pertanian Di Daerah Aliran Sungai (DAS) Cianjur, Jawa Barat [disertasi]. Bogor: Program Pasca Sarjana Institute Pertanian Bogor. 2005 